\title{
Svitlana Usik
}

Marketing Department

Kyiv National University of Technologies and Design

\section{INTEGRATION PROSPECTS OF UKRAINE IN THE CONTEXT OF ENTERING INTO EUROPEAN UNION}

\begin{abstract}
The article describes the stages of entering procedure into European Union, criteria, which must be executed for entering into EU, and also generalizes positive and negative consequences of membership of Ukraine, in EU

Key words: Integration processes, World Trade Organization (WTO), European Union (EU), Ukraine
\end{abstract}

